\title{
De la producción a la recepción. Una propuesta de observación multi local y sincrónica para el análisis de noticias televisivas ${ }^{1}$
}

From production to reception. Multi local and synchronous observing proposal for analyzing crime news on tv

\section{Mercedes Calzado}

Consejo Nacional de Investigaciones Científicas y Técnicas (CONICET)

Instituto de Investigaciones Gino Germani. calzadom@gmail.com (ARGENTINA)

\section{VANESA Lio}

Consejo Nacional de Investigaciones Científicas y Técnicas (CONICET) Centro Interdisciplinario de Metodología de las Ciencias Sociales (IdIHCS-UNLP/

CONICET)

vanesa.lio@gmail.com (Argentina)

\section{Cristian Manchego Cardenas}

Consejo Interuniversitario Nacional Instituto de Investigaciones Gino Germani cristianmanchegoca@gmail.com (Argentina)

\author{
VICTORIA IRISARRI \\ Universidad de Buenos Aires (UBA) \\ victoria.irisarri@icloud.com (Argentina)
}

Recibido: 17.04 .2019

Aceptado: 21.02 .2020

\footnotetext{
${ }^{1}$ El artículo se enmarca en el Proyecto de Investigación Orientado de la Defensoría del Público-CONICET titulado "El género policial en el marco de las transformaciones del escenario audiovisual argentino. Rutinas productivas, representaciones mediáticas y recepción de la información sobre inseguridad en CABA y Córdoba" llevado adelante por equipos del Centro de Estudios Avanzados de la Universidad Nacional de Córdoba y del Instituto de Investigaciones Gino Germani de la Universidad de Buenos Aires. Los datos aquí utilizados son parte del relevamiento realizado por el equipo de la Ciudad de Buenos Aires.
} 


\title{
RESUMEN
}

Este artículo presenta un ejercicio metodológico realizado en el marco de un proyecto de investigación sobre los nuevos modos de construcción de la noticia policial en televisión. El tópico de la inseguridad se enmarca en un proceso social, cultural y político vinculado al crecimiento de la violencia y el delito en las sociedades contemporáneas, pero también al incremento y transformación de su visibilidad. Partiendo de la hipótesis de que los medios de comunicación son dispositivos centrales en la construcción del espacio de lo público, indagamos en la producción de contenidos sobre "inseguridad" en noticieros de televisión, en los modos de acceso a las fuentes, circulación de la información, estrategias de presentación de las noticias y la forma en que las audiencias las decodifican e interpretan. Para esto, nos propusimos observar, en forma simultánea, tres espacios/situaciones durante la emisión de un noticiero central de un canal de aire de la Ciudad Autónoma de Buenos Aires. Por un lado, en la instancia de producción, la sala de control y el móvil principal del día. Por otro, incorporamos la recepción visualizando en vivo el mismo noticiero en un ámbito familiar. La experiencia implicó la participación de cuatro investigadores en tres locaciones distintas. El objetivo es presentar la potencialidad y dificultades que emergieron de este ejercicio de observación participante grupal y multisituada.

\section{PALABRAS CLAVE}

Etnografía, multi local, noticias, televisión, medios.

\begin{abstract}
This article presents a methodological exercise carried out as part of a research project on the new modes of construction of police news on television in Argentina. The topic of insecurity is part of a social, cultural and political process linked to the growth of violence and crime in contemporary societies, but also to the increase and transformation of its visibility. From the hypothesis that the media are central in the construction of public spaces, we investigate the production of content regarding "insecurity" in television news, focusing on the ways of accessing the sources, circulation of information, news presentation strategies and how audiences decode and interpret them. To reach this objective, we observe simultaneously three space-situations during a central TV news show broadcast by an over-the-air channel in Buenos Aires. On one hand, we analyze the production of news, from the broadcasting room and the main live reporting from the street. On the other hand, we also study news reception by visualizing the same TV show in a family environment. The experience involved the participation of four researchers in three different locations. The paper presents the
\end{abstract}


potentiality and difficulties that emerged from this multi local and synchronic observation exercise.

\section{KEY WORDS}

Ethnography, multi local, news, television, media.

\section{INTRODUCCIÓN}

Recortar un tema, recortar un objeto, recortar un marco conceptual y un marco metodológico. Este artículo representa el recorte del recorte, un ejercicio puntual a partir del cual experimentar las potencialidades y dificultades de una matriz metodológica para el análisis múltiple de las noticias televisivas. ¿Cómo se produce la información en los noticieros de canales de televisión abierta? ¿En qué espacios? ¿Cuáles son sus contenidos? ¿Cómo la reciben e interpretan las audiencias? Preguntas heterogéneas que solo pueden tener respuestas desde un abordaje multi local y sincrónico.

El objetivo de estas páginas es presentar una propuesta metodológica desde un ejercicio que tomó un momento determinado de producción y recepción durante una hora de un noticiero de mediodía de un canal de aire de la Ciudad de Buenos Aires y lo analizó de forma multi local y sincrónica. El ejercicio en sí mismo cuenta con escasos antecedentes. Una de las pocas matrices puestas en juego en esta línea fue la realizada por el Nationwide Project del Centre for Contemporary Studies de la Universidad de Birmingham a fines de la década del setenta e inicios del ochenta. Desde el modelo múltiple de la codificación y decodificación propuesto por Stuart Hall (1980), este estudio buscó revisar la emisión y la recepción de noticias. Así, la investigación encabezada por Brunsdon (1978) y Morley (1980) articuló el análisis del contenido de Nationwide, un programa noticioso televisivo, con la lectura dominante, opuesta y negociada de sus espectadores ${ }^{2}$.

Pese a la riqueza de estos abordajes integrales, las perspectivas metodológicas de las investigaciones sobre noticias televisivas suelen centrarse en sólo uno de los momentos del circuito comunicativo. Por ejemplo, las investigaciones que revisan desde una mirada etnográfica los procesos de producción y recepción televisiva en general, y periodísticos en particular, definen matrices de trabajo específica para un determinado entorno. En este grupo ubicamos la etnografía en producción realizada por Born (2004) en la British Broadcasting Corporation (BBC) en Inglaterra, cuyo fin fue revisar los desafíos de la institución ante los

2 Esta investigación es un antecedente interesante para nuestro trabajo. Sin embargo, como veremos más adelante, investigar formas de producción y recepción de noticias televisivas actualmente presenta nuevos desafíos vinculados a la incorporación de nuevos medios de producción tecnológicos como es el smartphone. 
cambios tecnológicos, políticos, sociales y culturales de la época (Born, 2004: 5). En recepción, por su parte, encontramos textos clásicos sobre la relación entre contenidos y audiencias en términos cualitativos que reparan en las características culturales de las audiencias (Ang 1996; Lull 1994; Morley 1996).

A este conjunto de revisiones con un corte etnográfico podemos sumar los trabajos que toman como objeto de estudio específicamente la noticia policial desde una perspectiva comunicacional. Sus propuestas metodológicas también se centran en un momento del circuito comunicativo. En algunos casos lo hacen desde el contenido (Surette 1992; Ericson et al 1991; Howitt 1998; Barak 1994; Ford y Longo 1999), otras desde la recepción (Focás y Galar 2016; Landi 1987 y 1992; Quesada 1999, Silvera y Natalevich 2012) y otras consideran las formas que asume la producción de noticias (Luchessi y Martini 2004; Born 2004). Por lo tanto, son pocos los trabajos hallados que se arriesgan a un armado metodológico capaz de revisar de manera simultánea las diversas variables del entorno comunicativo. Asimismo, podríamos afirmar que son escasos los abordajes metodológicos de la producción, contenido y recepción de la noticia en televisión, ya que en general la información policial suele ser estudiada desde sus contenidos gráficos, tanto en Argentina, como en Latinoamérica (Arfuch 1997; Baquero 2017; Bonilla Vélez y Tamayo Gómez 2007; Fernández Pedemonte 2001; García Beaudoux y D’Adamo 2007; Lara Kar y Portillo Vargas 2004; Lorenc Valcarce 2005; Martini y Pereyra 2009; Rey y Rincón 2007; Sánchez 2014; Sunkel 1985; Tufró 2017; Vilker 2008).

En estas páginas buscamos retomar los avances de estas investigaciones y presentar herramientas que aporten a una matriz metodológica de abordaje integral de la noticia policial desde la producción y desde la recepción, sin abandonar las características del contenido. El ejercicio fue parte de la búsqueda más amplia de un proyecto de investigación que apunta a comprender de manera compleja a los actores y variables de la noticia policial en televisión desde las relaciones existentes entre el sistema mediático argentino, las transformaciones del espacio público y el vínculo del género policial con los modos en que los sujetos experimentan el delito urbano. El tópico de la inseguridad se enmarca en un proceso social, cultural y político vinculado con el crecimiento de la violencia y el delito en las sociedades contemporáneas, pero también con el incremento y la transformación de su visibilidad mediática. Entendiendo que los medios de comunicación son dispositivos centrales, aunque no los únicos, en la construcción del espacio de lo público y lo inseguro, la línea de investigación en la que se inserta este artículo indaga en la producción de contenidos policiales en noticieros de televisión, en los modos de acceso a las fuentes, circulación de la información, estrategias de presentación de las noticias y la forma en que las audiencias las decodifican e interpretan.

Para revisar de manera particular la hipótesis general del proyecto nos propusimos observar, en forma simultánea, tres espacios/situaciones durante la emisión de un noticiero central de aire de la Ciudad Autónoma de Buenos Aires. Por un lado, revisamos la instancia de producción, desde la sala de control, el plató y el móvil principal del día. Por otro, incorporamos la recepción visualizando en 
vivo del mismo noticiero en un ámbito familiar. Por último, tomamos nota de los contenidos informativos transmitidos por el noticiero. El experimento implicó la participación de cuatro investigadores en tres locaciones distintas: $\mathrm{M}$ y $\mathrm{V}$ en las instalaciones del canal, $\mathrm{C}$ en el móvil y $\mathrm{F}$ en la instancia de recepción.

El objetivo particular de este trabajo es delinear una propuesta metodológica para analizar las noticias televisivas que articule los niveles del contenido, la producción y la recepción de la información. En este sentido, nos preguntamos qué puede aportar un abordaje integral del circuito comunicativo que indague estas tres distintas instancias de manera multi local y simultánea. ¿Cómo articular la observación y el análisis de estos tres niveles? ¿De qué manera hacer dialogar las instancias de producción y recepción? ¿Cómo operan las modalidades, las rutinas y los espacios de generación de contenidos en la interpretación que hacen las audiencias?

Con este horizonte, en las próximas líneas presentamos las características de esta experiencia, las decisiones tomadas, así como las potencialidades y dificultades que emergieron de este ejercicio de observación grupal, multi localizada y sincrónica.

\section{APORTES PARA UN ABORDAJE INTEGRAL DEL CIRCUITO COMUNICATIVO}

Los contenidos mediáticos son producidos y leídos en un espacio cultural determinado. De allí que para analizar cómo las producciones televisivas categorizan el mundo (y cómo desde ellos nos categorizamos en tanto sujetos) debemos evitar una serie de riesgos. El primero es realizar un análisis en solo un punto del circuito comunicativo. Ello implica situarnos tanto donde se producen como donde se interpretan las imágenes y palabras mediáticas. Debemos, a la vez, resistir otra tentación: revisar de qué modo se construye y de qué modo se lee lo producido únicamente desde el mensaje. En este aspecto, la apuesta semiótica es relevante para entender el ecosistema mediático y los sentidos de sus textos, pero limita la posibilidad de hallar gran parte de las significaciones de la palabra y prácticas silenciosas de los actores. De allí la riqueza de un abordaje etnográfico, que multiplica la posibilidad de revisar los sentidos en tanto los mensajes, los sujetos y sus prácticas forman parte central de la observación del analista.

Para avanzar en nuestro desafío de reconocimiento del todo comunicativo como modo de comprender los sentidos puestos en juego por la noticia policial audiovisual contemporánea, tomamos la propuesta de la antropóloga Lila AbuLughod $(2004,2005)$ respecto del análisis multisituado de los sentidos mediáticos $^{3}$. Este análisis fue tomado como inspiración para pensar y desarrollar un

${ }^{3}$ Lila Abu-Lughod tomó el modelo desarrollado por George Marcus (1995) de etnografía multisituada, destacando las posibilidades de movilidad espacial que este modelo proponía. Al correrse de la ubicación singular para el trabajo de campo, la etnografía multisituada permite “... analizar la circulación de los sentidos culturales, los objetos e identidades en espacios-tiempos 
abordaje que tenga al mismo tiempo en cuenta diversos espacios de producción y recepción de noticias policiales en una misma ciudad y en un mismo espacio temporal. Este ejercicio, al igual que el planteado por Abu-Lughod, nos permitió abordar los mundos cotidianos de las personas con quienes trabajamos en distintas locaciones con la intención de revelar las conexiones que existen entre ellos. Desde este enfoque revisamos las particularidades del lugar de la producción de noticias, de los textos televisivo-informativos, de su recepción y de la dinámica cultural que se observa en sus articulaciones y contradicciones; es decir, los diversos "nódulos de la vida social de la televisión" (Abu-Lughod, 2005: 33).

Sin embargo, este abordaje etnográfico reveló al mismo tiempo algunos contrastes con la propuesta realizada por Abu-Lughod. A diferencia del trabajo desarrollado por la antropóloga en Egipto, nuestro objeto de estudio no se preocupó en esta instancia por insertar su análisis en el sistema-mundo ${ }^{4}$. La experiencia que presentamos en este artículo a propósito de las noticias televisivas abarcó un circuito territorial específico que puede ser seguido y circunscripto, y a su vez se inscribió en una temporalidad única, sincrónica, en la que las diferentes situaciones de campo son registradas simultáneamente.

Las circunstancias específicas de hacer trabajo de campo con periodistas con quienes no siempre es posible pasar largas y continuas jornadas laborales (porque las empresas no habilitan estadías prolongadas, o porque los periodistas tienen una variedad de trabajos que hace difícil poder acompañarlos) nos obligó a diseñar una propuesta para seguir la circulación de las noticias policiales, desde su producción (en diversos ámbitos) y recepción (también en una multiplicidad de ambientes), pero no de forma abstracta sino localizada (Abu-Lughod 2005). Específicamente desde la producción, la etnografía multi local, sincrónica y en equipo permitió, como veremos a continuación, abordar diferentes momentos y espacios de producción de noticias policiales. En cuanto a la recepción de noticias, este tipo de matriz permitió, en un primer nivel, comprender la diversidad de modos de consumo ${ }^{5}$ y apropiación de la información, que contrasta con la hipótesis de que los medios instalan de modo homogéneo una idea sobre el tema y los efectos que producen socialmente ${ }^{6}$. En un segundo nivel, este abordaje ha-

difusos" (Abu-Lughod 2004). La apropiación de este modelo para el estudio de novelas televisivas en Egipto fue fructífero para la autora.

${ }_{4}$ El análisis multisituado fue pensado para etnografías que precisan "seguir al objeto" a una escala global, es decir, aquellos objetos o sujetos que no son posibles de ser ubicados en un único lugar y en un tiempo específico y continuo. Un ejemplo interesante de este tipo de trabajos es el desarrollado por Ulf Hannerz (2003). En una etnografía entre corresponsales de guerra la metodología multisituada es pertinente dado que, por el tipo de prácticas de sus interlocutores, las entradas y salidas del campo son esporádicas y en diferentes lugares del mundo, y no siempre es posible una estadía permanente y prolongada (Hannerz 2003: 213).

${ }^{5}$ El consumo es entendido aquí como la internalización de la cultura en la vida cotidiana (Miller 1998: 212).

${ }^{6}$ El modo en que entendemos el análisis de las audiencias difiere de aquellos abordajes centrados en la cuantificación de la recepción durante la emisión de los programas. A la vez, aunque entendemos la novedad que representan los avances de estudios como los de audiencia social, definida como la fragmentación que se produce en las audiencias a partir de la interactividad que habi- 
bilitó el análisis acerca de cómo noticias generadas por productores particulares circulan en audiencias específicas.

Otra dimensión significativa de nuestras decisiones se centró en la necesidad de enfocarnos no solo en un medio -en este caso la televisión-, sino en una multiplicidad de medios con los que las personas se involucran (Madianou 2002: 81), y que actualmente hacen a la producción, la reproducción y la recepción de noticias. La transformación profunda en el uso de tecnologías de comunicación cada vez más convergentes tiene implicancias en las formas de apropiación de la información que circula. Para poder analizar este fenómeno tomamos el concepto de polimedia, el cual surgió de la necesidad de describir y comprender la proliferación y oportunidades de medios para la comunicación interpersonal (Madianou y Miller 2013: 171). Si bien este concepto se desarrolló para analizar la elección y usos de medios de comunicación dentro de una plétora de opciones de los individuos, y está especialmente enfocado en las redes sociales, hicimos uso de esta noción para entender la manifestación de un entorno emergente de oportunidades comunicativas que funciona como una "estructura integrada" dentro de la cual cada medio se define en términos relacionales en el contexto de todos los demás. Esta perspectiva de análisis nos corrimos de una descripción centrada en las cualidades que cada medio tiene como una tecnología discreta, para entenderla como un entorno de recursos. Así, si bien a lo largo de nuestro trabajo de campo nos centramos en la televisión, observamos cómo se accede a una misma noticia desde diferentes dispositivos o redes sociales. Al abarcar la multiplicidad de tecnologías utilizadas, nuestro énfasis recayó en las consecuencias sociales y emocionales (Madianou y Miller 2013: 173) de elegir entre las diversas alternativas mediáticas, y no en las restricciones de cada uno (en general vinculados al acceso por costo o por conectividad). Teniendo en cuenta este escenario, buscamos comprender qué sentidos adquieren en cada ocasión y con relación a los diferentes dispositivos mediáticos ${ }^{7}$.

\footnotetext{
litan en las redes sociales y que se orientan a medir la actividad generada en Twitter al momento de la emisión de un programa (Bredl et al 2014; Claes et al 2013; Deller y Hallam 2011; Harrington et al 2013; Quintas-Froufe y González-Neira 2014, entre otros), nuestra propuesta procura revisar las audiencias no como un espacio de consumo medible, sino como un espacio de generación de sentido. En el mismo sentido, si bien no es el concepto desde el que abordamos este trabajo, la noción de televisión social (Arrojo 2013; Gallego 2013; Lorente Cano 2011) permite revisar cómo la televisión en tanto tecnología pasa a asumir un rol interactivo al integrar a los telespectadores a través de los comentarios en su propia pantalla o a través de otros dispositivos (desde las redes sociales a través de celulares, tablets, computadoras). Nuestro esfuerzo, por lo tanto, se centra en la interpretación de la audiencia como parte de un contexto cultural que debe ser revisado en sus multiplicidades y complejidades.

7 La propuesta es entender a los medios tal como se definen por su relación entre ellos y no en sí mismos (Madianou y Miller 2013).
} 


\subsection{Preparativos y momentos iniciales}

Nuestro ejercicio consistió en investigar los medios desde lo medios, y desde allí surgió uno de los primeros retos metodológicos. Los tiempos y las rutinas del trabajo periodístico impidieron en varias oportunidades concretar los encuentros pautados con presentadores, productores y cronistas. Lograr la simultaneidad en la observación de las distintas instancias del circuito comunicativo implica también hacer coincidir las agendas de los múltiples actores, ya sea para acompañarlos y observar sus tareas cotidianas o para entrevistarlos. Una particularidad, y un obstáculo, con que nos encontramos en este sentido fue la dinámica de organización de los móviles diarios en los canales de televisión. De acuerdo con la disponibilidad técnica de cada empresa, en la primera mañana se van definiendo las noticias que se consideran centrales y que, por lo tanto, ameritan la cobertura en vivo y en directo. Los principales canales de televisión cuentan con una serie de opciones para cubrir noticias en el lugar de los hechos: los móviles propios que transmiten por satélite (que se trasladan con una camioneta y suelen incluir en el equipo, al menos, un camarógrafo, un productor y un cronista); las "mochilas" (sistemas que permiten que una única persona transmita desde el lugar donde sucede el hecho noticiable a través de un dispositivo tecnológico que carga, como su nombre lo indica, en una mochila); y la comunicación telefónica con un cronista 8 .

Las definiciones, sin embargo, no solo dependen de los recursos tecnológicos y humanos, sino que implican negociaciones. En el caso de los canales de aire, los móviles pueden quedar establecidos por la agenda del noticiero de la franja horaria previa (los canales de aire suelen tener entre tres y cuatro noticieros diarios: primera mañana, mediodía, noche y medianoche). En el caso de los multimedios, al compartir recursos, deben acordar entre las prioridades de los canales de aire que incluyen noticieros en su programación y las emisoras de noticias 24 horas. En este sentido, la definición de los móviles se caracteriza por la imprevisibilidad y la inmediatez, lo cual incidió directamente en nuestra posibilidad de planificar el trabajo de campo con anterioridad.

Quizás por ser el último día de la semana; quizás por ser una mañana fría y gris; quizás por querer compartir sus saberes con alguien que venía de "la academia"; quizás solo por las coincidencias. Por alguno de estos quizás, el movilero del canal respondió muy rápidamente a las $8 \mathrm{AM}$ nuestro mensaje por WhatsApp: “¿Tenés algún móvil para que te acompañemos hoy?”, preguntamos. Le habíamos escrito varias veces, pero no habíamos coincidido; los tiempos televisivos no son los mismos que los tiempos de la investigación.

(Notas de campo. 21 de julio de 2017)

\footnotetext{
${ }^{8}$ Si bien este trabajo está centrado en la experiencia de observación de un noticiero de un canal de televisión por aire, algunas regularidades que describimos surgen de entrevistas realizadas, en el marco del proyecto mencionado, a periodistas, productores y presentadores de noticias de los canales de aire y de televisión por cable del Área Metropolitana de Buenos Aires (Televisión Pública, Telefé; América TV; Canal 13; Canal 9; C5N; TN; Crónica).
} 
La inserción en el campo se dio de modo simultáneo a partir del acceso a observar un móvil y el área de control dentro del estudio televisivo. A diferencia de la negociación realizada por Georgina Born (2005:16) para desarrollar su etnografía en la BBC, un ambiente cerrado y cargado de paranoia en donde el acceso fue limitado y renegociado de forma permanente a lo largo de los años, nuestro acceso fue por momentos fácil y descentralizado. Sorpresivamente, tuvimos la posibilidad de negociar cada entrada al canal puntual donde haríamos este ejercicio de forma particular con diferentes personas ${ }^{9}$. El acceso al control fue a través del productor ejecutivo, mientras que al móvil fue a través del periodista que cubría la noticia ese día. Al estudio de ese canal ya habíamos ingresado en varias oportunidades, habíamos realizado entrevistas a periodistas y productores (en particular al productor ejecutivo del noticiero que se convirtió en nuestro referente empírico), habíamos conocido los estudios de televisión y los distintos espacios de transmisión de los programas de noticias del canal de aire y de cable del multimedio. Pero recién tres meses después logramos ingresar al control en el momento de la emisión del noticiero. Complementar la presencia en el canal durante la transmisión con una observación del móvil de la principal noticia en la agenda del día permitió analizar integralmente de qué forma se produce la información en televisión, de qué manera se accede a la materia prima que luego es construida como noticia a partir de estrategias narrativas y enunciativas.

Dada la dinámica de la información policial, la elección de lo que será transmitido suele ser imprevisible. Así, la posibilidad de acompañar al reportero durante la cobertura del principal móvil del día surgió a último momento. El hecho policial elegido para abrir el programa, considerado por el equipo del noticiero como la noticia principal del día, había sucedido el día anterior a nuestro contacto en un municipio ubicado en la zona sur del aglomerado urbano conocido como Gran Buenos Aires. Sin embargo, el equipo de producción se mantenía atento al posible surgimiento de otro hecho policial más relevante en términos de su noticiabilidad. La confirmación se produjo a través de un mensaje de WhatsApp y tuvimos que comenzar a improvisar, resolver con velocidad los pasos siguientes: quién y cómo iría al móvil, cargar a último momento las baterías de celulares, buscar las coordenadas más adecuadas en el GPS para llegar a los destinos en un breve periodo de tiempo y no olvidar los anotadores.

Una de las transformaciones en la forma de producción de noticias, en especial en las noticias en vivo, es la incorporación de WhatsApp. Entre los productores y periodistas WhatsApp es visto como una herramienta para estar en conexión permanente a un costo muy bajo. La incorporación de tecnologías digitales como WhatsApp también ha permitido la reducción de profesionales en las empresas, dado que las consultas pueden hacerse a las personas con más experiencia sin importar el lugar físico donde se ubican. A cada paso, entre el equipo en el canal y el equipo en el móvil intercambiaban mensajes por Whats-

9 En los otros canales (públicos y privados) donde realizamos la investigación no fue tan sencillo concretar los accesos. Cada medio, cada gestión a su cargo y cada programa televisivo implican una grilla de regularidades que por una cuestión de extensión no abordaremos en este texto. 
App para ajustar el trabajo que estaba siendo realizado. Ese mismo mecanismo fue el utilizado por el equipo de investigación. WhatsApp nos permitía estar conectados entre nosotros, compartir observaciones en tiempo real, y poder hacer ajustes sobre qué observar o reorientar nuestras miradas.

Al igual que los periodistas y productores de noticias buscábamos acompañar cada momento de la definición acerca de cómo presentar y mostrar las noticias del control con el paso previo a la "cocina" de la información del móvil: la búsqueda de las materias primas que les permiten a los periodistas narrar los hechos. Es decir, ese rastreo de datos, testimonios e imágenes que ilustran la narración de los acontecimientos. Dado que íbamos a observar la producción de la información desde dos lugares (el estudio de televisión y el móvil), decidimos no perder la oportunidad de incorporar lo que sucedía en la recepción de las noticias: cuáles eran los sentidos que emergían entre quienes estaban mirando y comentando lo que allí acontecía. Por eso, el ejercicio puso un último pie en un hogar de otro punto del sur del conurbano bonaerense, donde F, la cuarta integrante del equipo de observación, almorzaba con una familia mientras miraba el noticiero y tomaba nota de todo lo que sucedía con la llegada de las imágenes y sonidos televisivos. La elección de esta familia se justificó por ser uno de los grupos donde veníamos realizando, en el marco del proyecto de investigación del cual este ejercicio forma parte, observaciones participantes y entrevistas etnográficas con audiencias de televisión.

Por lo tanto, la inmediatez de las definiciones que había que tomar en este ejercicio metodológico fue posible gracias al trabajo previo que veníamos realizando con la familia, con los periodistas del canal televisivo y con el análisis de las noticias. Por un lado, porque los contactos ya estaban entablados con nuestros interlocutores en los distintos ámbitos. Por otro, porque desde un análisis sistemático de los contenidos de los noticieros de televisión ya habíamos caracterizado en términos cuantitativos y cualitativos la información tematizada como policiales e inseguridad (Calzado et al 2019). Si lo primero nos permitió la celeridad en la organización de las tareas durante aquella mañana, lo segundo brindó herramientas para observar con mayor especificidad la emisión del noticiero.

A diferencia de las actividades que veníamos desarrollando en cada uno de estos espacios de investigación, este ejercicio habilitó no solo situarnos en más de un lugar, sino también que la observación fuera realizada en cada uno de ellos al mismo tiempo. Para los registros utilizamos diferentes soportes materiales que complementaban las funciones. Las libretas fueron un soporte para registrar movimientos y expresiones verbales, y también de los contenidos para luego analizar aspectos vinculados al enunciado y a la enunciación, a lo que las noticias dicen y cómo lo dicen. Los celulares fueron utilizados como soporte de grabación de lo que iba sucediendo, también para el registro fotográfico y, especialmente, como ya fue mencionado, para la conexión entre nosotros. Si la tecnología era parte central de nuestro objeto de estudio, también lo era de nuestra dinámica de investigación. El proceso de trabajo estaba mediado por el celular, como dispositivo de contacto y de captación de material. De este uso de los dispositivos surge una observación adicional: lejos de distanciarnos de nuestros interlocutores 
(todos ellos con celulares en mano durante la emisión), el celular hizo posible de alguna manera mimetizarnos, confundirnos con el contexto. De hecho, quizás el objeto más disonante en ese entorno fuera el anotador: mientras que nadie nos preguntaba por qué sacábamos fotos o filmábamos (incluso nos invitaban a hacerlo), la toma de notas en el modo analógico desentonaba en tiempos de la inmediatez de la comunicación digital.

Hasta aquí, dos cuestiones centrales de esta propuesta de observación grupal y multi-local. Por un lado, buscábamos solapar los resultados para integrar los planos de la emisión, el mensaje y la recepción en una paleta de sentidos alrededor de la noticia policial. Por otro, nuestras tareas se encontraron forzosamente mediadas por las nuevas tecnologías. Si bien en el equipo habíamos conversado con anterioridad acerca de las definiciones a tomar, un canal de comunicación instantáneo a través del celular fue importante para potenciar las decisiones y compartir al instante qué sucedía en cada uno de los espacios de observación. Como investigadores buscábamos acompañar en la recolección de los datos a los tiempos televisivos y hacerlo, además, de manera colectiva. En el mismo momento, pero no en el mismo espacio. Para los periodistas y productores el WhatsApp también era una herramienta de trabajo fundamental. Sin embargo, si bien tuvimos contacto con personas particulares de esos ámbitos e intercambiamos mensajes, nunca accedimos a formar parte del grupo de producción de WhatsApp. Como señalan Miller et at. (2016) este tipo de red social puede ser entendido como una sociabilidad en escalas, lo que permite un control de los vínculos y sus proximidades.

\subsection{El $h u b$ de las noticias}

La sala de control es el centro de mando, el lugar desde el cual se toman todas las decisiones durante la emisión de cualquier noticiero. Allí el director y el productor ejecutivo, junto al resto del equipo, coordinan todas las actividades, reciben las señales, procesan la información y definen los detalles de los contenidos a emitir.

Llegamos al canal poco antes del comienzo del noticiero y nos dirigimos directamente hacia la sala de control. Entramos y saludamos. El productor ejecutivo y el resto del equipo nos estaban esperando. Nos dicen que nos podemos acomodar donde queramos o podamos. Nos sentamos en el centro, un poco en medio del paso, porque la sala no es muy grande y es el lugar que encontramos. Es un ambiente cerrado y oscuro, salvo por la luz de las numerosas pantallas frente a nuestros rostros. No tiene conexión visual con el plató más allá del que se produce mediado por cámaras y pantallas. Sentimos que estamos por empezar a observar un espectáculo desde la primera fila. Consultamos sobre la posibilidad de tomar fotos, notas y pequeños videos. Nos aseguran que el registro no era un inconveniente en ningún sentido. Intercambiamos unas breves palabras y enseguida inicia el ritmo vertiginoso de la emisión del programa. Nuestra presencia no parece incomodar ni distraer a 
ninguno de ellos. Nos hacen chistes y comentarios, pero cada uno sigue con su tarea y nuestra mirada no altera la rutina.

(Notas de campo, 21 de julio de 2017)

El equipo del control estaba integrado por ocho personas y el clima de trabajo era distendido: charlaban, hacían bromas e incluso alguno sacaba su mirada de la pantalla principal para mirar la de su teléfono personal. Los roles y las labores de cada uno estaban bien definidos. Los puestos de trabajo se distribuían en dos filas, todos orientados hacia el mismo lugar, una pared cubierta por pantallas donde se visualizaban imágenes diversas: lo que sale al aire, lo que está por salir, las señales que ingresan por satélite, lo que toman las distintas cámaras en el estudio y en los móviles, los otros canales de noticias. Sobre un costado, en un monitor aparte, se veían los números del "minuto a minuto" de Ibope ${ }^{10}$. Justo en el centro de la primera fila frente a la gran pared de pantallas se ubicaba el director de cámaras y el productor ejecutivo (ver imagen 1). El primero seleccionaba qué salía al aire, controlaba y definía qué se veía. El segundo era la voz de mando: coordinaba el noticiero en general, decidía el orden y orientaba lo que se dicía. A la derecha del productor ejecutivo una mujer, la única en la sala de control, se ocupaba de tener "en puerta" todos los paños y las notas previamente editadas. Es decir, las tenía disponibles a través de un software para que el director de cámaras las pudiera seleccionar y poner al aire. Al lado de ella, un hombre manejaba el programa mediante el cual se transmiten a los conductores, a través de otra pantalla ubicada en el estudio, las noticias próximas a salir. Allí, los presentadores leen los títulos y los zócalos (las bajadas o copetes) previamente redactados. Hacia la izquierda del director de cámaras, se ubicaban las dos personas encargadas del audio: el musicalizador y el sonidista/microfonista. Por último, en la segunda fila, un escalón por encima se encontraba, de un lado, el generador de imágenes: de archivo, fotos, placas, infografías, etcétera. Del otro, el generador de caracteres: es decir, de todos los títulos y textos que aparecen sobre la pantalla.

${ }^{10}$ Ibope es una empresa de servicios dedicada a realizar mediciones de audiencia en los medios de comunicación en Argentina, fundamentalmente de radio y televisión. 
Imagen 1. Vista de la sala de control. Pared central con pantallas.

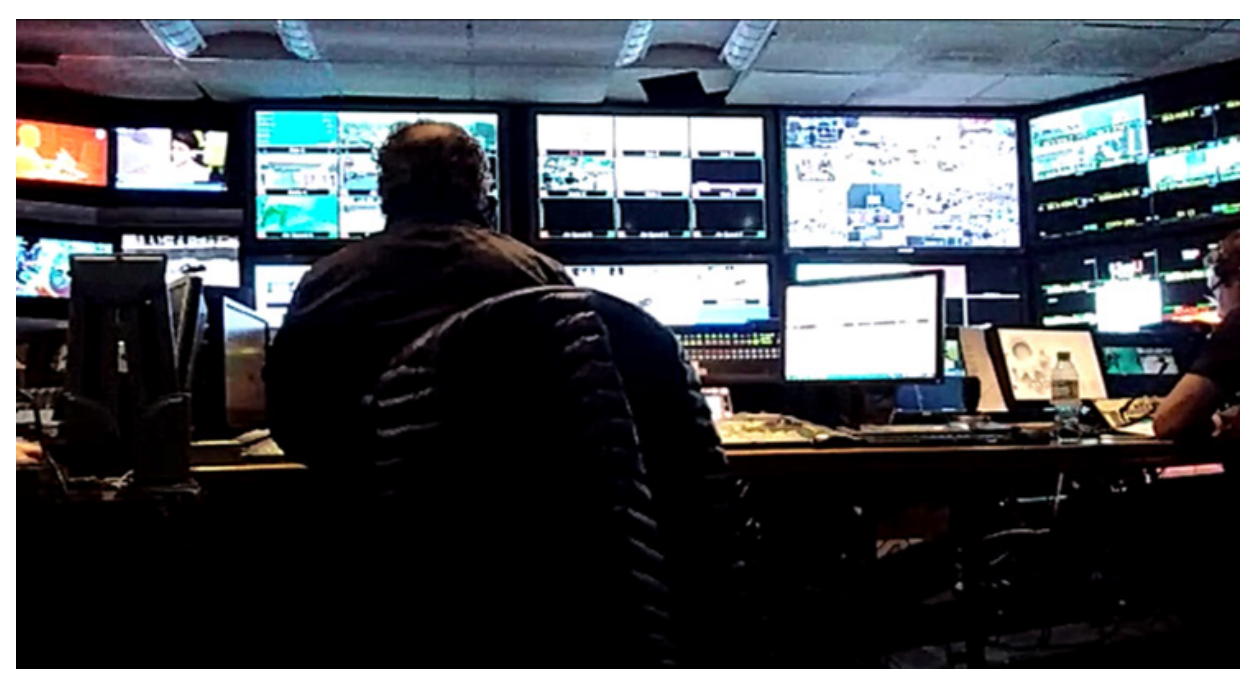

Fuente: imagen propia.

Al interior del control observamos distintos planos de diálogos: los que transcurrían al aire; los que sucedían entre productor y conductores o movileros (que los televidentes no podían escuchar ni percibir); y los que se circunscribían al interior de la sala de control (que, obviamente, no percibían ni los televidentes ni los conductores o movileros). Cuando las conversaciones se superponían, una voz al mando decía en un tono fuerte "ojo que voy" y la concentración volvía a lo que estaba saliendo al aire.

Si bien todo noticiero tiene un guión, muchas decisiones se toman sobre la marcha. “¿Pongo imagen sensible?”, preguntó en voz alta quien se ocupaba del videograph -los textos y títulos leídos en la pantalla- al aparecer en el monitor una mujer con sangre en su frente. "Si tenés duda, tiralo", respondió enseguida el productor ejecutivo, sin referirse a que lo desechara, sino a que lo incluyera veloz y preventivamente sobre la imagen como mensaje de aviso al espectador. Como ésta, algunas otras cuestiones se definían mientras el noticiero sucedía. Los tiempos televisivos pueden incidir en el esquema, pero sin modificarlo completamente. El rating minuto a minuto no parecía ser un protagonista fundamental en este control, al menos durante la emisión del programa. Durante la charla, los trabajadores nos explicaron que solamente puede haber un cambio brusco en el plan, un "volantazo", si la noticia es un urgente que justifique reemplazar (y, en general, desechar) el contenido ya dispuesto para el programa. Sin embargo, las mediciones de audiencia no estaban del todo ausentes. "Si vas a anotar por qué justificamos todo, es por el rating", nos explicaba el productor ejecutivo mientras mirábamos en las pantallas imágenes de un oso que manejaba una moto y un ganso hacía footing. 
Los números del minuto a minuto también estuvieron presentes antes del comienzo del programa: el productor ejecutivo advirtió a los conductores que "El Zorro" había "dejado bajo", haciendo alusión a que la tira de ficción que antecedía el noticiero no había alcanzado los niveles de audiencia habituales. Estas aclaraciones explícitas sobre el rating, que en este caso no preguntamos directamente, sino que surgieron de manera espontánea, nos ubicaron rápidamente en el lugar de observadoras externas. A pesar de que este tipo de vínculo con los interlocutores puede ser recurrente en las investigaciones etnográficas (Bourgois 2010; Guber 2011), hay algo del objeto que le confiere cierta especificidad. Conocemos las lógicas de la noticia en televisión por ser televidentes, podemos analizar con una mirada teórica los discursos y contenidos televisivos como comunicólogas. Sin embargo, carecemos de los conocimientos prácticos y específicos sobre el cómo y el porqué de la generación de noticias policiales en televisión; no contamos, en la mirada de nuestros interlocutores, con el know how de los especialistas. Esto nos ubicó, al mismo tiempo, adentro y afuera, en una relación que por momentos estaba teñida por la complicidad de quienes comparten competencias, y, por otros, por cierta distancia generada por la disparidad en los saberes prácticos.

En la dinámica de la sala de control, las bromas y los chistes sobre lo que se decía y lo que se veía en pantalla parecían ser habituales y constantes:

En el monitor "del aire" se está proyectando el videoclip de la canción "La Tonta", junto con una entrevista a la cantante y actriz Jimena Barón en la que expresa entre líneas que le dedicó el tema a su expareja, el futbolista Daniel Osvaldo. Un murmullo de bar invade el control. Tanto allí como en el plató, observamos charlas simultáneas y superpuestas, conversaciones informales entre quienes comentan y alimentan una polémica mediática. "Decile que venimos con dos muertos", advierte uno de los hombres de la producción. El clima cambia en el control, en el plató y en la pantalla. Hay algo de la muerte que demanda respeto. Se genera un silencio. Un barrido y una placa que dice "alerta" anuncian el cambio de tono: el conductor se pone serio, el musicalizador acompaña con un tema acorde a lo policial, que genera tensión. El sonido de la música es el que les anuncia la vuelta de página, y el cambio en la entonación de la presentación. El conductor sobreactúa la seriedad y en el control vuelven las risas: "Madre de dios", dice uno de ellos. "Yo creo que a la gente le da vergüenza ajena", agrega otro sobre el cierre del bloque.

(Notas de campo. 21 de julio de 2017)

Hay dos elementos que observamos se preparan con anterioridad y completan lo que se ve y escucha por pantalla durante la emisión del noticiero: las imágenes y la música. Por un lado, las imágenes de archivo, con las que "pisan" a los conductores mientras relatan una noticia, son seleccionadas previamente. Durante la emisión del programa, el generador de imágenes, que se ocupa del "arte electrónico", tenía algunas opciones preparadas y la decisión final se tomaba en cuestión de segundos de entre una carta visual que se exhibía en las pantallas de la pared central. El director de cámaras iba seleccionando la imagen más adecuada para acompañar el relato de los presentadores. Aunque era él quien tenía 
la última palabra, la decisión parecía, al menos en este aspecto, consensuada. Algo similar sucedía con las entrevistas que los movileros hacían en vivo. Desde el control, donde se concentraban mucho más que dos oídos escuchando el testimonio, le indicaban al cronista hacia dónde ir: qué preguntar, en qué enfatizar.

Por otro lado, la musicalización se considera como un elemento central para generar los climas deseados, quizás el más importante. La observación desde el control nos permitió identificar que el canal cuenta con un archivo de temas para los distintos noticieros y secciones. El jefe de musicalización se ocupa de seleccionar las melodías y mantener actualizado el repositorio musical. "Cada seis meses se renueva -nos explicó el musicalizador en una entrevista que realizamos una vez finalizado el noticiero- y el canal tiene artistas contratados que van generando pistas". Luego, el encargado de musicalizar cada programa le da su "impronta", seleccionando los temas que acompañan cada noticia minutos antes de cada emisión. "Ve el orden y lee las noticias un rato antes y él ya sabe qué puede poner", nos explicó el productor ejecutivo del noticiero. Para policiales se suelen utilizar distintos tracks, "algunos más de terror", otros "más de misterio", otros "más trágicos" y otros más neutros. "Debe haber más de 300 tracks para policiales y para este noticiero usamos unos 60", especificó el musicalizador. Salvo alguna indicación específica, nadie parecía interferir demasiado en ese trabajo. La música no era algo que se discutiera en el control, como sí lo era qué imagen poner, qué título priorizar o qué tono dar.

La música es un momento de producción y decisión previo al de la sala de control del noticiero, lo cual implica una limitación al ejercicio propuesto. No obstante, en términos teórico-metodológicos, la importancia de la música en este género televisivo abre nuevos interrogantes a ser indagados. ¿Quiénes son los músicos contratados para este trabajo? ¿Qué tipo de especificidades son requeridas? ¿Qué trayectorias tienen estos músicos? Y, por otro lado, ¿cómo es recibida esa música por parte de las audiencias? ¿Cómo la vinculan con las noticias que están viendo?

\subsection{El aquí y ahora de la noticia del día}

La observación desde la sala de control permitía entender las decisiones editoriales y estéticas de la producción de la noticia. Pero nada decía sobre la rutina por la que se capta la noticia en el lugar de los hechos, la voz de los actores involucrados, la relación del periodismo con ellos. Para identificar la totalidad de la rutina productiva de la generación de una noticia, debíamos sumar a nuestra matriz de trabajo la observación del segundo lugar donde se genera la información y su imagen: los móviles.

Dos unidades móviles de televisión se habían dirigido a la mañana temprano al barrio del sur bonaerense donde había sucedido el hecho. Habían asesinado al dueño de un supermercado chino y varios medios trabajaban en el lugar del acontecimiento. Llegamos cerca del mediodía al lugar. No hay aglomeración de vecinos alrededor de la escena, solo algunos observan desde 
las esquinas. El periodista escribe en su celular, al lado de la camioneta del equipo técnico del canal. Frente a ellos, otro enviado de un canal de noticias conversa con algunos de sus compañeros.

(Notas de campo. 21 de julio de 2017)

El desafío de nuestra experiencia metodológica implicaba estar en el lugar mismo donde las noticias son recogidas, entender el cómo y el porqué de un proceso que se iniciaba y concluía en el canal, pero cuyo material en crudo era extraído de otros territorios, alejados en algún punto de la lógica institucional de la empresa mediática. El reportero que venía siendo nuestro contacto clave fue fundamental para que la tarea de registro quebrara paso a paso los estadíos de aquello que se podía o no preguntar en el terreno. Si era posible grabar la conversación; si se podían tomar imágenes de la fachada del supermercado; fotografiar las anotaciones en las que escribía los principales datos del caso; si se podía conversar con los camarógrafos que lo acompañaban; si se podía saber sobre la importancia del rating durante la cobertura de un caso policial. Nuestro método se revisaba minuto a minuto a partir de las posibilidades que nos acercaba el conocimiento del campo del periodista. De hecho, las preguntas no causaban resquemor en el cronista, habituado a la dinámica de las entrevistas.

La tonalidad de su voz y la estructura de las frases que utilizaba el cronista se asemejaban a las que utilizaba frente a cámara. "Vení, vení, ¿querés ir viniendo?", "vos seguime", señalaba mientras nos desplazamos por el lugar del hecho. Transitar por el ámbito de trabajo, por su territorio, nos permitió observar e identificar los elementos de su narración: la ubicación de las cámaras de seguridad, el lugar donde permanecían los familiares de la víctima, el recorrido que podría haber realizado el asesino desde que llegó al lugar hasta que escapó.

"Ahora vos me vas a ver parado. Yo hablo y los camarógrafos van ponchando. Para el noticiero de la señal de noticias yo voy, recorro. Ahora no hace falta", comentó el reportero respecto de la presentación del caso en vivo para el noticiero del canal de aire. El equipo estaba compuesto por cinco personas: el periodista y otros cuatro varones que se ocupaban de tareas técnicas (dos camarógrafos, el jefe de móvil y un asistente). Uno de los camarógrafos se ubicaba frente al cronista y su tarea era seguirlo (Ver Imagen 2). El otro debía concentrarse únicamente de los planos detalle. 


\section{Imagen 2. Vista del móvil. Cronista, camarógrafo y asistente técnico.}

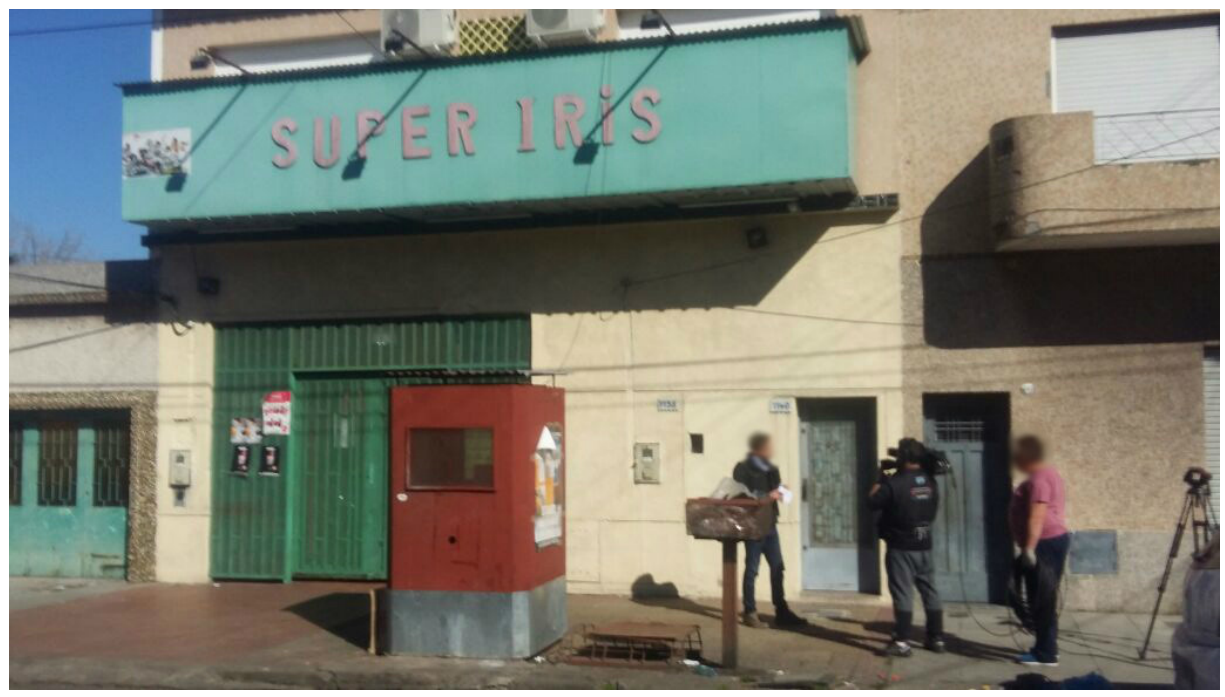

Fuente: Imagen propia

A través de una llamada telefónica a su celular pocos minutos antes del inicio de la transmisión en vivo, el cronista recibió instrucciones concisas desde la sala de control: "vender el móvil", "hablar del video y paño", "presentar el testimonio y paño", "volver [del paño] y hacer un cierre". El material estaba listo para esa secuencia. El caso había "explotado" el día anterior a las seis de la tarde y desde entonces el reportero se encontraba trabajando en el tema.

Para la realización de todo móvil, de acuerdo con lo que describió el cronista, es recomendable contar con dos ideales bien concretos: el "ideal del video" y el "ideal del testimonio". En este caso, el periodista tenía el video en su celular: una grabación realizada a un monitor que reproducía la filmación original de una cámara de seguridad. En el video se podía observar que a un hombre que ingresó al supermercado, buscó al dueño del negocio, sacó un arma y disparó. La pregunta acerca del origen del video generó algo de tensión e incertidumbre en la charla. De acuerdo con lo que venimos observando en nuestra investigación, este tipo de imágenes suelen llegar a través de fuentes policiales o judiciales por vías informales (Calzado et al 2017). El "ideal del testimonio" se pudo construir no con declaraciones de los familiares de la víctima, sino con una entrevista a una vecina del barrio. Las palabras de la testigo de este caso habían sido grabadas horas antes. El movilero comentó que llegó al lugar a las seis de la mañana, y el video y el testimonio habían sido producto de aquellas horas de trabajo. El material ya había sido publicado durante el noticiero emitido por el canal durante la mañana. "Si yo me quedo con lo que tenía de las seis de la mañana, para la tarde, ya es viejo", explicó el periodista antes de comentar que quería conseguir 
otro video. Su objetivo de máxima era una cámara de seguridad colocada en una casa justo en frente al supermercado.

La posibilidad de participar de la escena en la que se genera la información nos permitió entender el "ideal del testimonio", a partir del cual se jerarquiza a los posibles declarantes en escalafones.

Más familiares de la víctima llegan al lugar y esperan a que quienes estén dentro abran la puerta de la casa. Un colega de otro medio se acerca junto con un camarógrafo a una joven oriental del grupo y consigue algunas declaraciones. El reportero del canal y nosotros observamos a pocos metros del lugar.

(Notas de campo. 21 de julio de 2017)

Si hay "una persona china hablando de un crimen de la mafia china, vale oro", remarcó el periodista durante la conversación. "Diez segundos de esta mujer valen más que un minuto de la vecina", agregó. Testimonio y video forman parte de las herramientas con las que se construye el policial para el público. El reportero describía la figura del declarante en el proceso de construcción de la historia policial. A través de él, el televidente conoce el barrio y a la víctima: "La gente te traslada al barrio. El testimonio de esa mujer lleva al televidente al barrio". Detrás de cada elección o criterio de trabajo parecía haber una justificación que implicaba una interpretación sobre la teleaudiencia. El periodista reconoció también la ineficacia de contar un caso sólo a través del relato del notero. "Yo mañana estoy en otro lugar, pero a mí lo que me sirve es la testigo que conoce a este hombre", expresó. Es ella quien permitió un anclaje en la historia: recuerda a la víctima, valora al vecino asesinado, a sus familiares, la inseguridad en el barrio. Así, traslada al público al barrio. De allí a la empatía por lo sucedido parece haber pocos pasos.

La presentación del caso en vivo se realizó desde la vereda del supermercado (ver Imagen 2). Dos camarógrafos acompañaban el relato del periodista. El primero se posiciona frente al movilero. No dejaba por ningún momento de tomar al reportero. El segundo trabajaba desde la vereda contraria, cruzando la calle, y se encargaba de seguir el relato del reportero a través de la toma de imágenes del lugar.

Los minutos transcurrían sin demasiados momentos en los que el equipo coordinara actividades. Solo algunos comentarios entre el periodista y el jefe de móvil anticiparon el vivo. Las tareas parecían seguir el ritmo pautado por la rutina diaria. "Igual esto ya lo hacemos todos los días y ya sabemos qué hacer", indicó el camarógrafo.

El vivo del periodista concluye. Es hora de volver a casa. El taxi en el que se moviliza lo espera en la esquina del lugar. Estuvo allí desde que el reportero llegó en la mañana. El taxímetro ya marca unos seis cientos pesos. El relevo del equipo técnico del canal llega al lugar en un auto. Son cuatro. La unidad móvil se quedará un par de horas de la tarde para cubrir cualquier eventualidad del caso. Otro periodista del canal, según el movilero, llegará pronto para cubrir la nota en esa franja horaria. El día ha terminado para este cronista. Sube al auto y le indica al taxista con total familiaridad que lo deje 
en su casa.

(Notas de campo. 21 de julio de 2017)

El reto metodológico de seguir al cronista hasta el momento de lograr la entrevista y la observación fue parte fundamental de la posibilidad de construir un escenario múltiple para comprender la generación de la noticia. Sin la observación "desde el lugar de los hechos", no hubiéramos podido entender una parte fundamental de cómo se produce una noticia. El siguiente paso para comprender la totalidad del circuito comunicativo implicaba revisar el modo en que los televidentes interpretaban una construcción noticiosa que también poseía complejidades.

\subsection{La sangre en pantalla}

La tercera locación de nuestro experimento fue en una localidad a unos 30 kilómetros de la Ciudad de Buenos Aires. La escena transcurrió en un almuerzo familiar con un televisor. La familia, con la que veníamos haciendo una microetnografía sobre la recepción de noticias en televisión en el marco del proyecto, estaba conformada por Andrea (mujer de 59 años, dueña de casa y "jefa de hogar"), Fernando (23 años, estudiante e hijo de Andrea), Lucía (25 años, hija de Andrea, estudiante y empleada) y Susana (57 años, empleada del hogar y definida por los miembros de la familia como "la segunda madre de la casa") 11 .

Cuando llegamos a la casa el televisor ya estaba encendido en el canal del noticiero, pero con el programa que lo antecedía, "El Zorro", una serie filmada en la década del sesenta que Susana y Andrea veían cuando eran chicas. La historia de la serie era quizás anacrónica para un mediodía de 2017, su imagen y sonido mostraban claros signos de haber sido un tape que ya había entretenido a tres generaciones. Pero quizás algo de su mensaje perduraba en el sentido que el informativo intentaba transmitir: el periodismo justiciero que busca marcar qué es el mal y qué es el bien, no con una espada, pero sí con las imágenes y los sonidos que imprime a cada transmisión.

La cortina de "El Zorro" inunda el ambiente mientras ultiman los detalles de la comida. "En su corcel, cuando sale la luna, aparece el bravo Zorro. Al hombre del mal él sabrá castigar, marcando la Z de Zorro", tararean de cortina de la ficción. El noticiero es el principal invitado al almuerzo familiar. En la mesa cuentan que lo sintonizan porque se trata de una compañía "divertida", con "risas y música para arriba, de viernes". El inicio del noticiero los encuentra distraídos por el almuerzo, pero la realidad los mete rápidamente dentro de la pantalla.

(Notas de campo. 21 de julio de 2017)

${ }^{11}$ Los nombres de los integrantes de la familia fueron modificados para mantener su anonimato.

EMPIRIA. Revista de Metodología de Ciencias Sociales. N. ${ }^{\circ} 47$ mayo-agosto, 2020, pp. 185-212.

ISSN: 1139-5737, DOI/ empiria.47.2020.27429 
El primer bloque del día comenzaba, como sucede por lo general con los noticieros del mediodía, con temas policiales y judiciales. Los informes realizados por la Defensoría del Público de Servicios de Comunicación Audiovisual (2018) muestran una sobre representación televisiva de las noticias sobre la cuestión criminal: entre 2013 y 2017 el tópico "policiales e inseguridad" fue el que concentró mayor número de noticias y mayor cantidad de minutos en pantalla sobre el total de los informativos de los cinco canales de televisión abierta. A esto se suma que las noticias policiales suelen ocupar un mayor tiempo promedio en relación con el resto de las noticias, ya sean de política, información general o deportes, lo que muestra no solo la presencia de la temática sino la relevancia noticiosa que se les otorga. Y, en particular, las emisiones del mediodía y de la noche (las que concentran mayores niveles de audiencia) presentan una proporción mayor de noticias policiales, que tiende a acercarse al 30 por ciento del total de informativo (Calzado et al 2019).

En una entrevista que realizamos previo a este ejercicio, el productor ejecutivo del programa describía una serie de cuestiones que justificaban la importancia otorgada a las noticias vinculadas con la "inseguridad" a pesar de no hacer "un noticiero netamente policial". La primera es la disponibilidad de una mayor cantidad de imágenes:

"Antes vos estabas esperando que una agencia de noticias te mande algo. Hoy te dicen todo el tiempo: 'mirá este video'. Salen cosas que sube la gente. Se dan muchas noticias internacionales en video y también muchos policiales en video. Hoy en día se graba todo y en la mayoría de policiales hay videos. Eso te da un poquito más de espectacularidad y por eso se apuesta a la imagen. Nos da más posibilidades de meternos en el policial porque hoy se puede contar mejor porque hay más imágenes".

(Entrevista al productor ejecutivo del noticiero. 17 de julio de 2017)

La segunda de las formas de justificar el lugar otorgado al policial se vincula con las demandas de la audiencia: "La seguridad es la demanda principal de la sociedad. Es decir, a la clase alta le pasa lo misma a una clase baja: está indefensa. Nosotros como noticiero le damos mucha importancia a esa lucha”, afirmó el mismo productor. Y, por último, la tercera es más bien de tono personal y estilístico:

"Por lo general la primera parte del programa es donde están los móviles. Bueno, quizás de los tres o cuatro móviles que tenemos en el aire, dos o tres son historias policiales, porque creemos que ahí encontramos un espacio donde la gente nos mira y a mí también me gusta un poco cubrir ese tipo de notas, es un gusto personal. Particularmente me gustan esas historias, siempre los policiales tienen eso que genera como un misterio. Donde vos tenés dos o tres hipótesis y el periodista se puede meter y con datos puede ir para un lado o ir para otro".

(Entrevista al productor ejecutivo del noticiero. 17 de julio de 2017).

Estas características que veníamos observando en el trabajo de campo previo, tanto a partir del análisis del contenido de los noticieros (Calzado et al 2019) 
como en las entrevistas realizadas a trabajadores de los canales de televisión (Calzado y Lio 2020), aparecían nuevamente en el marco de este ejercicio y nos hicieron pensar ciertas claves de lectura transversales, sólo posibles a partir de la articulación entre los distintos espacios de observación propuestos por esta apuesta metodológica.

Mientras almuerzan milanesas en la cocina del hogar, observan la primera imagen que emite el noticiero: un video tomado por un celular en el que un grupo de policías golpea a un grupo de chicos en una plaza de una ciudad que queda a una hora y veinte en auto del lugar donde viven. A pesar de no estar nada cerca, Andrea comenta la noticia con el resto de los comensales: "Acá también hubo un quilombo asî". Fernando, el más joven, explica que "no habían visto nada en la calle". Pero ella asegura que lo sabía porque "Ramón ("un conocido" que maneja una cuenta en la red social "Facebook" con el nombre de la ciudad) había publicado una foto sobre un "lío en la plaza".

(Notas de campo. 21 de julio de 2017)

Una matriz metodológica de abordaje múltiple era la solución para enfrentar el reto que implicaba revisar la articulación entre la producción de las noticias y la comprensión de los televidentes. La forma en que la imagen de lo lejano repercute en la interpretación de la noticia es a partir de una imagen local que circula como "dato" o rumor por una red social. El impacto de la noticia en la conversación familiar se daba así por la sensación de cercanía, producto de un hecho recibido por una red social y recordado a partir de su similitud. El modo en que se evidenciaba el impacto de la imagen lejana transmitida desde un canal de aire era a partir del vínculo con la cercanía. Esta es la primera clave de nuestra apuesta metodológica para entender la relación entre producción y recepción de la noticia policial.

La segunda pista surgió de la noticia que inmediatamente siguió el inicio de la emisión: un comerciante de un "supermercado chino" asesinado en una localidad de la zona sur del Conurbano Bonaerense por un supuesto "sicario" bajo el videograph "Fusilaron al chino".

Desde la mesa de la cocina, los espectadores visualizan un video de una cámara de seguridad que muestra cómo el "sicario" camina, saca un arma, entra al supermercado y apunta. La imagen se repite varias veces.

(Notas de campo. 21 de julio de 2017)

Esta es la clave de la imagen como centro de la información audiovisual: sin imagen no hay noticia o, mejor dicho, la noticia es lo que puede desprenderse y generarse a partir de esa imagen. Si nos detenemos en los contenidos de esa emisión del noticiero, observamos que todas las noticias policiales y de inseguridad de ese día incluían algún material generado a través de cámaras de seguridad o teléfonos celulares. De hecho, casi todas las noticias del programa recurrían a este tipo de imágenes y de videos encontrados en Internet o fotos sacadas de las redes sociales, incluso las noticias deportivas e internacionales. Esta característica expresa una regularidad observada en el análisis de contenidos de noticias 
de televisión que realizamos de forma paralela a este ejercicio metodológico: la incorporación de las nuevas tecnologías como fuentes de la información policial y una elasticidad del tópico policial al adquirir elementos de las noticias de información general (Calzado et al 2019).

El reportero anticipa desde la pantalla que se trata de un crimen vinculado con la "mafia china". A los más jóvenes les causa gracia la certeza de esta definición. El periodista suma luego el dato de que "le dieron dos tiros a un cliente". Ahí sí, entonces, se escucha en la mesa por lo bajo, "uf, qué bajón”.

(Notas de campo. 21 de julio de 2017)

La "cercanía", en este caso dada por la empatía con la víctima, funcionaba como movilizante de quienes escuchaban. El supermercadista chino no producía esa misma empatía, pero sí lo hacía el cliente.

De acuerdo con la mirada de los espectadores, el caso producía sensaciones diferenciales. Ello sucedió, por ejemplo, cuando el reportero entrevistó en vivo a una vecina que no tuvo dudas en vincular el hecho con un incendio que había sucedido diez años atrás, cuando recién abría el supermercado. El más joven de la familia comentó que la hipótesis de la vecina le generaba cierta incredulidad. Incluso él y su hermana rieron cuando en el noticiero los conductores afirmaron que se trataba "evidentemente de recurrentes crímenes", aunque ya habían pasado diez años. En cambio, la madre encontró lógica en esta hipótesis: "Esta fue una advertencia de la mafia para marcar el terreno tipo 'mirá lo que te podemos hacer, mejor pagá'. Ahora andá a saber qué pasó”, comentó.

El reto que enfrentamos al momento de poner en juego nuestro abordaje metodológico tenía que ver con estar en condiciones de hallar conexiones entre escenarios de producción de sentido que suelen ser analizados de manera desarticulada. La posibilidad de comprender estos vínculos surgía del mismo hecho de realizar una observación en espacios múltiples bajo la producción y recepción del mismo contenido. Así, pudimos verificar que la misma imagen varias veces transmitida y los comentarios de los periodistas llevaron a los espectadores de ese mediodía a intercambiar opiniones, a participar de la conversación propuesta por la pantalla, sin que ello se convirtiera en una discusión sobre el tema. De alguna manera, los comentarios de los comensales acompañaron los comentarios de los que hacían la noticia. Todo el primer bloque consistió en relatar noticias vinculadas con casos policiales, solo vieron muy brevemente avances de otras noticias de deportes y espectáculos. Pero para cerrar el primer bloque había que distender. Allí el segmento de información general y la presentación del tema de Jimena Barón logran que la tanda comercial llegue con la sonrisa de los comensales.

Tercera clave: la atención flotante. Los ánimos y la atención cambian especialmente al compás de la musicalización propuesta por la producción. Poder dar cuenta de esta relación solo fue posible gracias al abordaje sincrónico y multilocal. De la misma forma que sucede en el canal, quienes miraban el noticiero tenían una atención latente respecto de lo que sucedía. Cuando el sonido (la música especialmente, aunque también el tono de quienes hablan) les llamaba 
la atención, los espectadores volcaron su mirada a la pantalla para observar las imágenes y los comentarios de los presentadores. Parecían saber qué sucedía a partir de las pistas que le ofrecían los sonidos, no era necesario atender permanentemente al noticiero.

La cuarta clave: la noticia policial, mirar la sangre en la pantalla, mueve a risa, mueve a temor, mueve a preocupación, o no mueve a nada. Todos estos estados de ánimo pueden estar contrapuestos en la misma noticia y se pueden modificar de a acuerdo a la regla de la recordación de otros hechos similares, estados de ánimo o alguna memoria emotiva que acompañe el hecho y, claro, la cercanía/empatía con el caso y la víctima. Durante el almuerzo, por ejemplo, los comensales discutían la noticia de una cita falsa realizada por redes sociales que terminó en un asesinato. Los jóvenes se rieron del caso y coincidieron con Susana en que pensaban que se trataba de una noticia cuya víctima era una chica. Pero cuando el relato resultó ser de un hombre que usó una red social para citas y lo engañaron, lo mataron y con la llave de su casa entraron a robar, la percepción sobre lo sucedido no fue fuerte, la empatía de las mujeres seguramente tampoco. Para el joven, si era mujer u hombre no implicaba un tema de reflexión. El conductor aseguró al aire que estas redes (aunque sin aclarar cuáles específicamente) "se usan para engaños, para robos y para crímenes". Los dos jóvenes rieron por lo taxativo de la presentación y de las fotos que acompañan el relato. Ni cercanía ni empatía. Para un muchacho que conocía el uso de las redes, el caso era poco de probable y poco creíble.

Por lo tanto, la observación nos permitía acercarnos a la hipótesis metodológica según la cual las claves de producción y lectura sólo podían ser identificadas integralmente en tanto las observaciones se realizaran en paralelo y bajo la dirección impuesta por el mismo contenido. El reto de abordar las diversas vías del circuito comunicativo pudo ser resuelto gracias a las definiciones metodológicas que nos brindó una perspectiva no determinista ni causalista.

\section{PALABRAS FINALES. ¿POR QUÉ UN EJERCICIO GRUPAL, MULTI LOCAL Y SINCRÓNICO?}

La literatura científica previa revisada para este estudio indicó que son escasos los abordajes de los procesos comunicativos en términos integrales. Ello responde tanto a una cuestión de perspectiva teórica como de definición metodológica. En ambos casos el resultado se basa en el énfasis producido en el análisis de uno de los momentos de proceso: o bien el foco está puesto en la emisión, o bien en la recepción, o bien en el contenido. Nuestro ejercicio buscó ser una contribución metodológica que revise las dificultades y las virtudes de la revisión integral del circuito de la producción y lectura de noticias televisivas.

De allí que, en tanto ejercicio metodológico, la experiencia que presentamos supone una serie de potencialidades que pueden ser explotadas y profundizadas. En primer lugar, la observación en diferentes ámbitos, es decir, la posibilidad de observar y registrar lo que sucede en distintos espacios en forma simultánea 
representa un valor metodológico para los estudios de la comunicación. La potencialidad de revisar los procesos de producción de noticias y de lectura de los televidentes implica valorar el desafío de una perspectiva cultural de las investigaciones sobre los medios y avanzar en esta línea.

En segundo lugar, y como consecuencia de lo anterior, un ejercicio multi local nos permite comparar y relacionar los modos en que los actores se desenvuelven en cada uno de esos ámbitos, observando cómo las acciones están, en muchos casos, encadenadas a otros procesos que suceden a distancia. Al mismo tiempo, es posible detenernos en aspectos particulares de los modos en que las acciones de unos son leídas e interpretadas por otros actores, y en qué medida esas lecturas se acercan o se distancian de los propósitos de los iniciadores de cada acción. En tercer lugar, la observación y el análisis colectivo permite incorporar distintas miradas a un mismo proceso comunicativo, potenciando la capacidad de descripción de un evento particular. En cuarto y último lugar, la indagación sincrónica en los distintos elementos o momentos de la comunicación permite superar un análisis lineal que se posicione solo en uno de los polos del proceso y en un solo medio de comunicación. La transformación en los medios de comunicación, especialmente dada por su convergencia, redefine las formas de producción y recepción de las noticias, y en especial la forma en que éstas son vivenciadas e incorporadas en la vida cotidiana. La elección de un medio u otro dentro de un conjunto de opciones disponible (polymedia), tanto para producir la noticia como para informarse, generan consecuencias sociales y emocionales diversas (Madianou y Miller 2013: 70) que abren nuevos interrogantes en los modos de mediación y precisan ser recogidas.

Al mismo tiempo, también identificamos ciertas dificultades antes, durante y después de la realización del ejercicio. Entendemos que explicitarlas y discutirlas brevemente aquí es una vía para desandar el camino recorrido y esbozar direcciones futuras. Una de las primeras dificultades de este ejercicio particular se vincula con las limitaciones de una generalización a partir de una única observación. Sin embargo, por un lado, al enmarcarse el trabajo en una investigación más amplia, que incluyó trabajo de campo en la producción de las noticias, la recepción de la información por parte de las audiencias y el análisis de los contenidos que se transmiten, el ejercicio nos permite establecer diálogos entre los resultados específicos de esta experiencia concreta y los hallazgos más amplios del proyecto. Por otro lado, entendemos que estos estudios puntuales y situados permiten la emergencia de nuevas preguntas de investigación, que nos orientan los próximos pasos de la indagación sobre las transformaciones de las noticias de inseguridad en el escenario audiovisual argentino. ¿Los objetivos planteados desde las rutinas productivas repercuten de tal forma en las audiencias? ¿Sucede lo mismo en los distintos segmentos de quienes se exponen a esas noticias? ¿Qué contenidos tienen mayor performatividad vivencial para las audiencias? ¿Es posible establecer reglas de visualización desde estos resultados? ¿Hay contenidos que generan malestar?

Un segundo elemento por mencionar son los trabajos etnográficos grupales. A la vez que identificamos la pluralidad de miradas como una potencialidad del 
ejercicio, esto mismo representa un desafío. Es necesario, para esto, un trabajo previo para coincidir en los objetivos y las miradas, en los modos de registrar y tomar notas de campo. En particular, en nuestro caso no fueron distintos investigadores, con sus improntas específicas, mirando lo mismo, sino que son miradas diversas sobre momentos/espacios diferentes de un mismo proceso. Puede, de hecho, ser prolífera la rotación de los roles o la especialización de cada investigador/a en uno de los aspectos para tener distintas miradas. Estas variables son importantes de revisar de cara a la repetición de un ejercicio con características similares a futuro y, a la vez, para dejar marcos de definición de nuestra experiencia más general del proyecto del cual forman parte los resultados aquí presentados.

\section{BIBLIOGRAFÍA}

ABU-LUGHOD, L. (2004): Dramas of nationhood. The politics of television in Egypt, Chicago, University of Chicago Press.

ABU-LUGHOD, L. (2005): "La interpretación de la(s) cultura(s) después de la televisión”, Etnografías contemporáneas, 1(1), pp. 57-90.

ANG, I. (1996) "Las guerras de la sala de estar. Nuevas tecnologías, índices de audiencia y tácticas en el consumo de la televisión", en Silverstone, R. y Hirsch, E. (eds.). Los efectos de la nueva comunicación. El consumo de la moderna tecnología en el hogar y la familia, Barcelona, Bosch.

ARFUCH, L. (1997): Crímenes y pecados. De los jóvenes en la crónica policial, Buenos Aires, UNICEF Argentina.

ARROJO, M. (2013): "La televisión social. Nuevas oportunidades y nuevos retos para el sector audiovisual", en Lloves, B. y Segado, F. (coords.), Actas del I Congreso Internacional de Comunicación y Sociedad Digital, Logrono, Universidad Internacional de La Rioja.

BAQUERO, R. (2017): "El crimen de Brian. La legitimación de la baja en la edad de imputabilidad en el discurso del diario Clarín", Question, 1(56), pp. 1-17.

BARAK, G. (1994): Media, process, and the social construction of crime: studies in newsmaking criminology, New York, Garland.

BREDL, K., KETZER, C., HÜNNIGER, J. y FLEISCHER, J. (2014): “Twitter and Social TV. Microblogging as a New Approach to Audience Research", en G. Patriarche, H. Bilandzic, J.L. Jensen y J. Jurisic (eds.), Audience Research Methodologies: between Innovation and Consolidation, New York, Routledge, pp. 196-201.

BONILLA VÉLEZ, J. y TAMAYO GÓMEZ, C. (2007): Los medios en las violencias y las violencias en los medios, Bogotá, CINEP.

BOURGOIS, P. (2010): En busca del respeto. Vendiendo crack en el barrio, Buenos Aires, Siglo XXI.

BORN, G. (2004): Uncertain Vision: Birt, Dyke and the Reinvention of the BBC, London, Secker and Warburg.

BRUNSDON, C. y MORLEY, D. (1978): Everyday Television: Nationwide, London, BFI. 
CALZADO, M., GÓMEZ, Y. y LIO, V. (2017): “Televisión, redes sociales y cámaras de seguridad. Hacia un nuevo mapa de la noticia audiovisual", en Ríos, C. (ed.), Memorias del IV Simposio Internacional LAVITS. ¿Nuevos Paradigmas de Vigilancia? Miradas desde América Latina, Buenos Aires, Fundación Vía Libre, pp. 87-96.

CALZADO, M., LIO, V. y GÓMEZ, Y. (2019): "Noticias policiales y nuevos modos de narrar la inseguridad en la televisión Argentina de aire", Ámbitos. Revista Internacional de Comunicación, 44, pp. 217-243, disponible en

https://revistascientificas.us.es/index.php/Ambitos/article/view/7855

[última consulta: 05-12-2019].

CALZADO, M. y LIO, V. (2020): "New Routines in the Production of TV Crime News in Argentina", en Wiest, J. (ed.), Crime, Criminals, and Mass Media, Bingley, UK, Esmerald Publising Limited (en prensa).

CLAES, F., OSTESO, J. y DELTELL, L. (2013): “Audiencias televisivas y líderes de opinión en Twitter. Caso de estudio: El Barco", Estudios sobre el Mensaje Periodístico, 19, pp. 347-364.

DEFENSORIA DEL PÚBLICO DE SERVICIOS DE COMUNICACIÓN AUDIOVISUAL (2018): Informe: 5 años de Monitoreo de Noticias (2013-2017), disponible en

https://defensadelpublico.gob.ar/wp-content/uploads/2018/10/5-años-de-MonitoreosDPSCA.pdf [última consulta: 11-12-2019].

DELLER, R. y HALLAM, S. (2011): “Twitteringon: Audience research and participation using Twitter", Participations. Journal of Audience \& Reception Studies, 8, pp. 216-245.

ERICSON, R., BARANEK, P., y CHAN, J. (1991): Representing order: crime, law, and justice in the news media, Toronto, University of Toronto.

FERNÁNDEZ PEDEMONTE, D. (2001): La violencia del relato. Discurso periodístico y casos policiales, Buenos Aires, La Crujía.

FOCÁS, B. y GALAR, S. (2016): "Inseguridad y medios de comunicación: Prácticas periodísticas y conformación de públicos para el delito en Argentina (2010-2015)", Delito y sociedad, 25(41), pp. 59-76.

FORD, A. y LONGO F. (1999): "La exasperación del caso. Algunos problemas

que plantea el creciente proceso de narrativización de la información de interés público", en Ford, A., La marca de la bestia. Identificaciones, desigualdades e infoentretenimiento en la sociedad contemporánea, Buenos Aires, Norma, pp. 245-288.

GALLEGO, F. (2013): "Social TV Analytics: Nuevas métricas para una nueva forma de ver televisión", Index Comunicación, 3, pp. 13-39

GARCÍA BEAUDOUX, V. y D'ADAMO, O. (2007): “Tratamiento del delito y la violencia en la prensa. Sus posibles efectos sobre la opinión pública", en Luchessi, L. y Rodríguez, M. (comps.), Fronteras globales, cultura, política y medios de comunicación, Buenos Aires, La Crujía, pp. 169-185.

GUBER, R. (2011): La etnografía. Método, campo y reflexividad, Buenos Aires, Siglo $\mathrm{XX}$.

HALL, S. (1980): “Codificar y Decodificar", en Culture, media and language, London, Hutchinson, pp. 129-139.

HANNERZ, U. (2003): "Being there... and there... and there! Reflections on Multi-Site Ethnography", Ethnography, 4(2), pp. 201-216.

HARRINGTON, S., HIGHFIELD, T. y BRUNS, A. (2013): "More than a backchannel: Twitter and television", Participations. Journal of Audience \& Reception Studies, 10, pp. 405-409 
HOWITT, D. (1998): Crime, the media and the law, Chichester England, New York, Wiley.

LANDI, O. (1987): "Mirando las noticias", en El discurso político. Lenguajes y acontecimientos, Buenos Aires, Hachette, pp. 169-197.

LANDI, O. (1992): Devórame otra vez. Qué hizo la televisión con la gente. Qué hace la gente con la televisión, Buenos Aires, Planeta.

LARA KAR, M. y PORTILLO VARGAS, J. (2004): Violencia y medios. Seguridad pública, noticias y construcción del miedo, México D.F., Instituto para la Seguridad y la Democracia.

LORENC VALCARCE, F. (2005): "El trabajo periodístico y los modos de producción de la noticia: el tratamiento de la inseguridad en la prensa argentina”, Question, 27, pp. 1-22.

LORENTE CANO, M. (2011): "Social TV en España: concepto, desarrollo e implicaciones", Cuadernos de Gestión de Información, 1, pp. 55-64.

LUCHESSI, L. y MARTINI, S (2004): Los que hacen la noticia. Periodismo, información y poder, Buenos Aires, Biblos.

LULL, J (1994): "Recepción televisiva, reforma y resistencia en China. Un estudio etnográfico", en Orozco, G. (comp.), Hablan los televidentes. Estudios de recepción en varios países, México DF, Universidad Iberoamericana, pp. 75-96.

MADIANOU, M. (2002): Mediating the nation: news, audiences and identities in contemporary Greece. PhD thesis, The London School of Economics and Political Science.

MADIANOU, M., y Miller, D. (2013): "Polymedia: Towards a new theory of digital media in interpersonal communication", International Journal of Cultural Studies, 16(2), pp. 169-187.

MARCUS, G. (1995): "Ethnography in/of the World System: The Emergence of MultiSited Ethnography”, Annual Review of Anthropology, 24, pp. 95-117.

MARTINI, S. y PEREYRA, M. (2009): La irrupción del delito en la vida cotidiana, Buenos Aires, Biblos.

MILLER, D. (1998): A theory of shopping, Ithaca, Cornell University Press.

MORLEY, D. (1980): The 'Nationwide' Audience: Structure and Decoding, London, BFI.

MORLEY, D. (1996): Televisión, audiencia y estudios culturales, Buenos Aires, Amorrortu.

QUESADA, M. (1999): "Violencia mediática y reacción social”, Ámbitos, 2, pp. 39-48.

QUINTAS-FROUFE, N. y GONZÁLEZ-NEIRA, A. (2013): “Audiencias activas: Participación de la audiencia social en televisión”, Comunicar, 43 (22), pp. 83-90.

REY, G y RINCÓN, O. (2007): Más allá de víctimas y culpables. Relatos de experiencias en seguridad ciudadana y comunicación, Bogotá, FES.

SÁNCHEZ, M. (2014): "Vivir en la inseguridad: Relatos sobre el delito y el control", La trama de la comunicación, 18 (1), pp. 135-149.

SILVERA, L. y NATALEVICH, M. (2012): "La crónica policial en los informativos de televisión”, Dixit, 16, pp. 4-12.

SUNKEL, G. (1985): Razón y pasión en la prensa popular. Un estudio sobre cultura popular, cultura de masas y cultura política, Santiago de Chile, ILET.

SURETTE, R. (1992): Media, crime, and criminal justice: images and realities, California, Brooks/Cole Pub. 
TUFRÓ, M. (2017): “Comunidades del miedo. Algunas observaciones sobre la construcción de los vecinos en la tematización de la «inseguridad» en Clarín”, en Martini, S. y M. Pereyra (comps.), La noticia hoy. Tensiones entre la política, el mercado y la tecnología, Buenos Aires, Imago Mundi, pp. 129-142.

VILKER, S. (2008): Truculencias: La prensa policial entre el terrorismo de estado y la inseguridad, Buenos Aires, Prometeo. 